\title{
A CFD approach to assess the effects of different opening combinations in poultry houses
}

\author{
Jairo A. O. Saraz ${ }^{1}$, Keller S. O. Rocha², Flavio A. Damasceno³, \\ Ilda F. F. Tinoco ${ }^{2}$, Robinson Osorio ${ }^{1} \&$ Julio C. A. Tobón ${ }^{1}$ \\ ${ }^{1}$ Universidad Nacional de Colombia sede Medellin/Departamento de Ingenieria Agricola y de Alimentos. Medellin, Colombia. E-mail: aosorio@unal.edu.co; \\ rosorio0@unal.edu.co; jcarango@unal.edu.co \\ ${ }^{2}$ Universidade Federal de Viçosa/Departamento de Engenharia Agricola e Ambiental. Viçosa, MG. E-mail: kellersullivan@yahoo.com.br; iftinoco@ufv.br \\ ${ }^{3}$ Universidade Federal de Lavras/Departamento de Engenharia. Lavras, MG. E-mail: flavio.damasceno@deg.ufla.br (Corresponding author)
}

\section{Key words:}

natural ventilation

ammonia concentration

computational simulation

\begin{abstract}
A B S T R A C T
The aim of this study was to use computational fluids dynamics (CFD) to evaluate hygiene and comfort conditions in function of temperature level and ammonia $\left(\mathrm{NH}_{3}\right)$ concentration during the night in commercial poultry houses used in Brazil and countries with tropical and subtropical climates. Four models with different curtain heights and different air inlet and outlet positions were used, adopting the open building typology without thermal insulation. The validated CFD model did not present statistical differences from the experimental data, making it possible to use this model to predict the behavior in the four proposed cases. This model can be used to improve the internal conditions of the poultry facilities during the night and could be an important tool to reduce energy consumption and generate better conditions for animal production of chicks over 21 days old.
\end{abstract}

Palavras-chave:

ventilação natural concentração de amônia modelagem computacional

\section{Uma abordagem em DFC para avaliar os efeitos das diferentes combinações de abertura em aviários}

\begin{abstract}
R E S U M O
O objetivo deste trabalho foi utilizar a dinâmica de fluidos computacional (DFC) para avaliar as condições de higiene e conforto, em função dos níveis de temperatura e concentração de amônia $\left(\mathrm{NH}_{3}\right)$ durante a noite, em galpões avícolas comerciais no Brasil e em países com climas tropicais e subtropicais. Para isto, foram utilizados quatro modelos com diferentes posições de altura, cortina com entrada e saída de ar adotando a tipologia de instalação aberta, sem isolamento térmico. O modelo em DFC validado não apresentou diferenças estatísticas com os dados experimentais, o que torna possível usá-lo para prever o comportamento dos quatro casos propostos. Este modelo pode ser usado para a melhoria da condição interna das instalações de aves durante a noite podendo, também, ser uma ferramenta importante para reduzir o consumo de energia e criar melhores condições para a produção de aves com idade superior a 21 dias de idade.
\end{abstract}




\section{INTRODUCTION}

The poultry industry in tropical and subtropical countries such as Brazil utilizes open poultry houses that work with open lateral walls without mechanical ventilation during most of the day, and the main difficulty with natural ventilation occurs during the night, when the air temperature can drop to levels below the recommended range for the thermal comfort of the chicks (Mendes et al., 2014; Saraz et al., 2016).

In the poultry industry in countries with tropical and subtropical climates, it is common practice to carry out sanitary control of poultry houses during night-time conditions in temperatures ranging between 10 and $15{ }^{\circ} \mathrm{C}$. This is done using natural ventilation by opening the curtains along the sides of the building or by using mechanical systems with minimal ventilation generated by exhaust fans (Menegali et al., 2009; Osorio et al., 2016). However, problems have arisen as a result of this practice, such as poor air quality and reduction of temperatures to below the level of thermal comfort, among others (Vigoderis et al., 2010).

In order to prevent this problem, Cassuce et al. (2013) recommended that to provide thermal comfort, the conditions should fall into the following ranges: temperatures between 21 and $27^{\circ} \mathrm{C}$, relative humidity (RH) of 50 to $70 \%$, and air speed of 0.5 to $1.5 \mathrm{~m} \mathrm{~s}^{-1}$. On the other hand, the current exposure limit for ammonia of $25 \mathrm{ppm}$ is set on the basis of human safety rather than animal welfare (NIOSH, 2001). An efficient natural ventilation configuration is necessary to improve air quality and indoor thermal comfort in the animal facilities, and one alternative way to carry this experiment is to use the computational fluids dynamics (CFD) technique (Seo et al., 2009; Norton et al., 2010; Damasceno et al., 2014; Saraz et al., 2016; Sousa et al., 2016).

The primary objective of this study was to use CFD to validate and assess the spatial distribution of temperature and $\mathrm{NH}_{3}$ concentrations in a typical installation without thermal insulation for the production of broilers aged over 21 days in tropical and subtropical climates under night-time conditions with outside temperatures ranging between 10 and $15^{\circ} \mathrm{C}$.

\section{Material AND Methods}

\section{Operational conditions of the experimental installation}

In this study, a commercial poultry house near the city of Viçosa, MG, Brazil, located $648 \mathrm{~m}$ above sea level at a latitude of $20^{\circ} 45^{\prime} 14^{\prime \prime} \mathrm{S}$ and longitude of $42^{\circ} 52^{\prime} 55^{\prime \prime} \mathrm{W}$, which is part of the integrated system of Pif Paf Alimentos S/A, was used for the experimental observations. According to the Köppen classification, the climate of the region is Cwb: a high-altitude tropical climate with wet summers and pleasant temperatures. This study was performed during the summer, with an average temperature of $15^{\circ} \mathrm{C}$ and $\mathrm{RH}$ varying between 50 and $70 \%$.

The commercial poultry building housed $14,000 \mathrm{Cobb}$ chickens, with a housing density of 14 chicks per square meter. The building measured $100 \mathrm{~m}$ in length and $13.0 \mathrm{~m}$ in width with a ceiling height of $2.1 \mathrm{~m}, 0.50 \mathrm{~m}$ overhang, and roof with an inclination of $20^{\circ}$, oriented in the east-west direction. Under low temperature conditions, especially at night, the lateral polyethylene curtains of the poultry houses were almost completely closed, thus limiting renewal of air inside the installation, and when the temperature inside the building was higher than $25^{\circ} \mathrm{C}$, the lateral curtains were opened.

\section{Experimental data collection}

Experimental data were obtained on three consecutive days in each week of the life of the chicks during the night when they were 22-28, 29-35, and 36-48 days old.

The $\mathrm{RH}$ and temperature of the air outside the poultry house were obtained using independent systems (Hobo H8032 ) with an accuracy of \pm 0.7 at $21^{\circ} \mathrm{C}$. Data collection was performed at one-second intervals.

A One Wire ${ }^{\mathrm{TM}}$ system based on the STRADA methodology, defined by Rocha et al. (2014), was used to determine the temperature inside the poultry house, where 24 sensors were used throughout the installation at three different heights from the floor $(0.2,1.2$, and $2.2 \mathrm{~m})$. The temperature data were obtained each second.

Data on $\mathrm{NH}_{3}$ concentration in the environment were obtained by means of an electrochemical detector, the BW GasAlert Extreme Ammonia $\left(\mathrm{NH}_{3}\right)$ Detector, with a measuring range between 0 and $100 \mathrm{ppm}$, operating temperature between -4 and $+40{ }^{\circ} \mathrm{C}$, $\mathrm{RH}$ from 15 to $90 \%$, and accuracy of $\pm 2 \%$. Measurements were taken at each of the 24 points at $20 \mathrm{~min}$ intervals.

Air velocity $\left(\mathrm{m} \mathrm{s}^{-1}\right)$ was obtained at each of the 24 points using a digital thermo-anemometer (Testo 425) with a range of $0-20 \mathrm{~m} \mathrm{~s}^{-1}$ and accuracies of $1 \%$ (pressure), 2.5\% (air velocity), and $0.1{ }^{\circ} \mathrm{C}$ (temperature). Measurements were taken at 20 min intervals. The temperatures of the roof and ceiling were measured with an ICEL model TD95 infrared thermometer, which had a range of -20 to $+270{ }^{\circ} \mathrm{C}$, a resolution of $1{ }^{\circ} \mathrm{C}$, and an accuracy of $\pm 2 \%$.

The Saraz Method for Determination of Ammonia Emissions (SMDAE) proposed by Saraz et al. (2015) and Sousa et al. (2016) was used for measurement of the ammonia mass flux generated from the bedding.

\section{Computational modeling}

Due to the large geometry of the installation, an experimental and modeled area of $50 \mathrm{~m}$ long by $13.0 \mathrm{~m}$ wide was used (Figure 1) with the aim of reducing the computational domain. Ventilation rates are associated with turbulent and combined flows in different directions and rates of heat transfer to generate a system of complex coupled equations. Thus
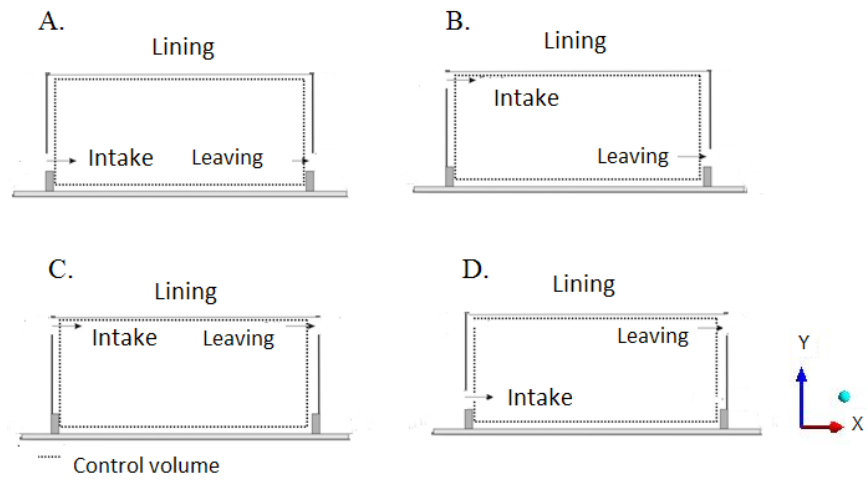

Figure 1. Schematic representation of the simulated cases 
CFD modeling is used to predict the results with the available experimental data. The ANSYS CFX ${ }^{\circledR}$ technique was used for solving the Navier-Stokes and energy equations, discretizing the fields of velocity, temperature, and pressure by the finite volume technique.

$$
\begin{gathered}
\frac{\partial \rho}{\partial \mathrm{t}}+\nabla \cdot(\rho \mathrm{U})=0 \\
\frac{\partial(\rho \mathrm{U})}{\partial \mathrm{t}}+\nabla \cdot(\rho \mathrm{UU})=\nabla \mathrm{p}+\left[\mu_{\tau}\left(\nabla \mathrm{U}+\nabla \mathrm{U}^{\mathrm{T}}\right)\right] \\
\frac{\partial\left(\mathrm{C}_{\mathrm{p}} \mathrm{T}\right)}{\partial \mathrm{t}}+\nabla \cdot\left(-\mathrm{k} \nabla \mathrm{T}+\rho \mathrm{C}_{\mathrm{p}} \mathrm{TU}\right)=0 \\
\frac{\partial \mathrm{C}_{\mathrm{A}}}{\partial \mathrm{t}}+\overrightarrow{\mathrm{m}} \cdot \nabla \mathrm{C}_{\mathrm{A}}=\nabla \cdot\left(\mathrm{D} \nabla \mathrm{C}_{\mathrm{A}}\right)
\end{gathered}
$$

where:

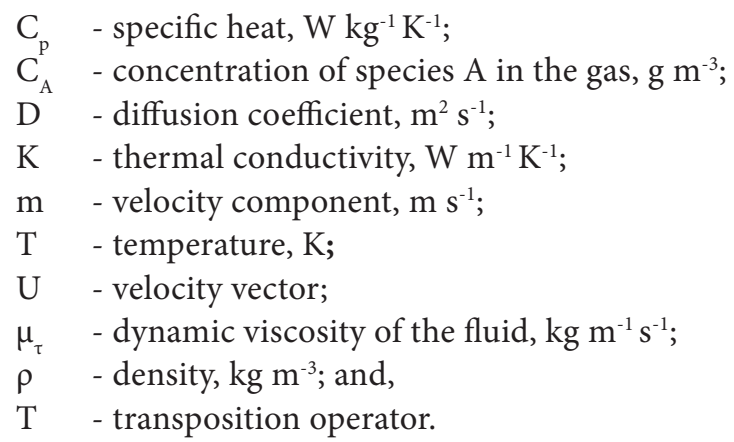

Turbulent flow was modeled using the $\mathrm{k}-\varepsilon$ standard model, which adds an extra stress (Reynolds stress) in the viscosity $\left(\mu_{\tau}\right)$. This model relates the turbulent kinetic energy (k) and dissipation of turbulent kinetic energy $(\varepsilon)$. The model that describes non-isothermal fluid flow is described by the equations of mass, continuity, energy, and species, simplified as follows (Rocha et al., 2013, 2014):

$$
\mu_{\tau}=C_{\mu} \rho \frac{\kappa^{2}}{\varepsilon}
$$

where the values of $k-\varepsilon$ are obtained by means of the equations:

$$
\begin{aligned}
& -\nabla\left[\left(\eta+\rho \frac{\mathrm{C}_{\mu}}{\sigma_{\kappa}} \frac{\kappa^{2}}{\varepsilon}\right) \nabla \kappa\right]+\rho \mathrm{U} \cdot \nabla \kappa=\rho \frac{\mathrm{C}_{\mu}}{\sigma_{\kappa}} \frac{\kappa^{2}}{\varepsilon}+\left(\nabla \mathrm{U}+\nabla \mathrm{U}^{\mathrm{T}}\right)^{2}-\rho \varepsilon \\
& -\nabla\left[\left(\eta+\rho \frac{\mathrm{C}_{\mu}}{\sigma_{\kappa}} \frac{\kappa^{2}}{\varepsilon}\right) \nabla \kappa\right]+\rho \mathrm{U} \cdot \nabla \varepsilon=\rho \mathrm{C}_{\mathrm{s} 1} \mathrm{C} \mu \kappa+\left(\nabla \mathrm{U}+\nabla \mathrm{U}^{\mathrm{T}}\right)^{2}-\rho \mathrm{C}_{\mathrm{s} 2} \frac{\mathrm{s}^{2}}{\kappa}
\end{aligned}
$$

Different levels of hexahedral mesh refinement were generated using the computational mesh of the ANSYS ICEM-

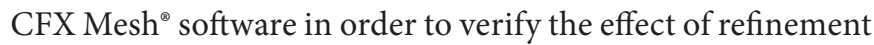
on the local concentration gradients in space and time. Because the installation used a false ceiling during the experimental period, the model generated with the mesh did not take the roof into account.
The results obtained from the simulations were verified and compared with the corresponding data in the mesh test and data, such as the $\mathrm{NH}_{3}$ concentration and mass flux obtained experimentally using a non-parametric one-way analysis of variance (Kruskal-Wallis test) with a sample of 24 experimental measurements taken at different sensor positions.

\section{Boundary conditions}

The CFD simulation of the poultry house carried out in the present work considered the following conditions: (a) steady state, used to validate the computational model with the experimental values; (b) transient regime, used to determine the behaviors of the temperature and ammonia distributions and their values over time in function of the air inlet and outlet positions in the lateral wall, (c) incompressible flow, and (d) turbulent flow.

The boundary conditions in CFX-Pre were as follows: a) the air speed was applied to the input area with the lateral curtains with a subsonic flow regime and normal velocity of $0.5 \mathrm{~m} \mathrm{~s}^{-1}$, which is the minimum allowed; b) the air speed was applied to the outlet area of the poultry house with a subsonic flow regime and average static pressure of $0 \mathrm{~Pa} ; \mathrm{c}$ ) the heat flux generated by the chicks $\left(Q_{c t}\right)$ was found in function of the environmental temperature of the building $(\mathrm{T})$ and body weight $\left(\mathrm{m}_{\mathrm{kg}}\right)$.

The heat flux generated by the chicks was estimated using the expression of Pedersen \& Thomsen (2000); d) the effect of variation of the barn floor temperature on ammonia flux

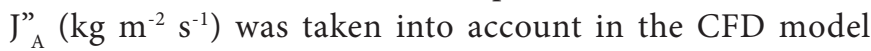
according to the results found and presented by Saraz et al. (2014) and Souza et al. (2016); e) for the interaction of the surface of the curtains with the inside air, a "no-slip" convective convection was assumed; and f) the roof lining temperature was assumed to be constant because it rapidly equates to the inside air temperature of the barn $\left(\mathrm{T}_{\text {indoor }}\right)$. Also, experimental data showed that when the outside air temperature reached $15^{\circ} \mathrm{C}$ and the housed chicks presented a small heat irradiation rate, the values of the roof lining temperature did not vary significantly (Saraz et al., 2016).

\section{Assessment of typical cases of air inlet and outlet in poultry houses with CFD model}

As is well known in South American countries such as Brazil, poultry producers make little use of mechanical systems for indoor air renewal during the night period in order to save energy. For this reason, producers usually allow natural ventilation of their poultry houses during the dark period, and different types of curtain management and air inlet and outlet configurations are applied without scientific knowledge of which configuration is more desirable (Menegali et al., 2009).

With the aim of improving the air quality and thermal comfort of the poultry houses (for chickens older than 21 days) in terms of $\mathrm{NH}_{3}$ removal and temperature control, during the night, only natural ventilation is used to achieve energy efficient consumption.

Four cases have been proposed with different air inlet and outlet configurations that are most commonly used in real conditions of the poultry industry in tropical and subtropical countries (Figure 1): case A, one air inlet and one outlet with 
openings measuring $0.40 \mathrm{~m}$, both located at a height of $\mathrm{Y}=$ $0.30 \mathrm{~m}$; case $\mathrm{B}$, one air inlet with an opening measuring $0.40 \mathrm{~m}$, located at the ceiling height of $\mathrm{Y}=2.1 \mathrm{~m}$, and an air outlet on the other lateral side with an opening measuring $0.40 \mathrm{~m}$, located at $\mathrm{Y}=0.30 \mathrm{~m}$; case $\mathrm{C}$, one air inlet and one outlet with openings measuring $0.40 \mathrm{~m}$, both located at the lining height at $\mathrm{Y}=2.1 \mathrm{~m}$; case $\mathrm{D}$, one air inlet with an opening of $0.40 \mathrm{~m}$ at $\mathrm{Y}=0.30 \mathrm{~m}$ and an outlet with an opening of $0.40 \mathrm{~m}$ at the height of the ceiling at $\mathrm{Y}=2.1 \mathrm{~m}$.

In all cases, the air renewal is performed by natural ventilation and is based on the principal that air passes through one predominant opening along one of the building walls, which is realized by generating natural barriers with afforestation to create pressure differences between the barriers and air intake along the sides of the shed.

The results from the CFD model were verified and compared to those corresponding to the experimental measurements. Concordance between the measured values and those described by the CFD model was also evaluated by calculating the normal mean square error (NMSE), as recommended by the American Society for Testing Materials (ASTM, 2002) (Eq. 8). Values with an NMSE less than 0.25 were accepted as good indicators of concordance; as this value approaches zero, the concordance between measured and predicted values is greater.

$$
\mathrm{NMSE}=\frac{\frac{1}{\mathrm{n}} \sum_{\mathrm{i}=1}^{\mathrm{n}}\left(\mathrm{Y}_{\mathrm{pi}}-\mathrm{Y}_{\mathrm{mi}}\right)^{2}}{\mathrm{Y}_{\mathrm{pi}} \mathrm{Y}_{\mathrm{mi}}}
$$

where:

$Y_{p}$ - predicted value; and,
$Y_{m}$ - measured value.

\section{Results AND Discussion}

A comparison between the data obtained by the model and the experimental data showed an NMSE of 0.0068 for $\mathrm{NH}_{3}(<0.25)$, indicating good agreement between the results (Table 1). Therefore, it was concluded that the proposed model can be used to accurately predict the $\mathrm{NH}_{3}$ concentrations in the indoor facility.

A test of the different meshes was carried out using ANSYS ICEM-CFD ${ }^{\circledR}$. Various types of hexahedral meshes were used after previously evaluating several levels of refinement. Thus, the selected mesh possesses 458.450 nodes and 710.334 elements (Figure 2).

Figure 3 shows the behavior of the velocity vectors along the XY plane of the installation. It can be observed that in most cases the velocities do not exceed half the velocity of air entering through the windward opening, and in those cases the

Table 1. Comparison of experimental and modeled data for $\mathrm{NH}_{3}$ concentration

\begin{tabular}{lccccc}
\hline & \multirow{n}{*}{} & \multicolumn{4}{c}{$\mathrm{NH}_{3}$ Concentration (ppm) } \\
\cline { 3 - 6 } Average & 24 & Experimental & Std Dev & CFD model & Std Dev \\
NMSE & 25.5 & 5.8 & 23.8 & 5.7 \\
\hline
\end{tabular}

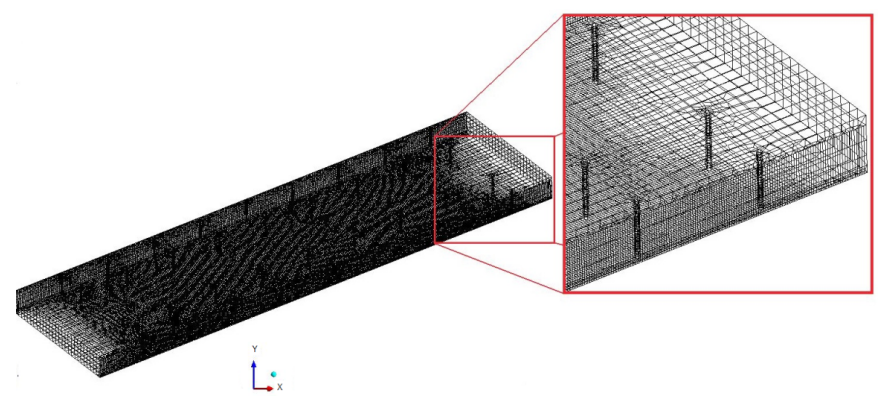

Figure 2. Detailed view of the hexahedral computational mesh

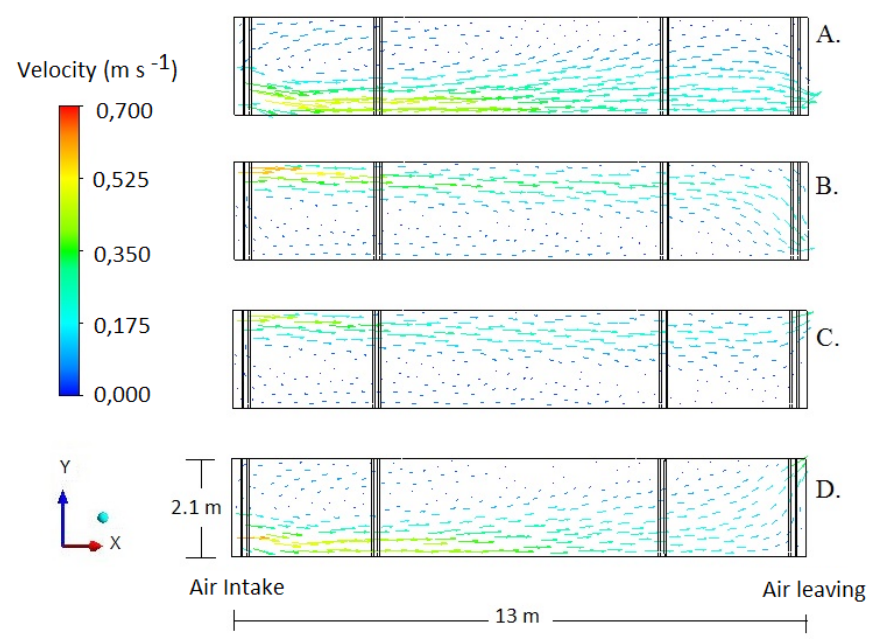

Figure 3. Velocity vectors for the different cases along the $X Y$ plane of the installation

average speed in the regions is $0.5 \mathrm{~m} \mathrm{~s}^{-1}$, In cases $\mathrm{A}$ and $\mathrm{D}$, the air speed at the height of the chicks is greater when compared with cases B and $\mathrm{C}$. In each case, these velocities are in the ranges reported by several researchers when observing natural ventilation. In cases $\mathrm{A}$ and $\mathrm{D}$, conditions are more suitable for the thermal comfort of the animals, with the air speed being $>0.5 \mathrm{~m} \mathrm{~s}^{-1}$ at the level of the animals (Cassuce et al., 2013).

The temperature distribution at steady state along the XY plane of the installation is shown in Figure 4 for the different cases. It was found that in cases $\mathrm{A}$ and $\mathrm{D}$, the temperature ranged between 11 and $20{ }^{\circ} \mathrm{C}$ at the height of the chicks in almost all of the facility, although in case $\mathrm{D}$, temperatures

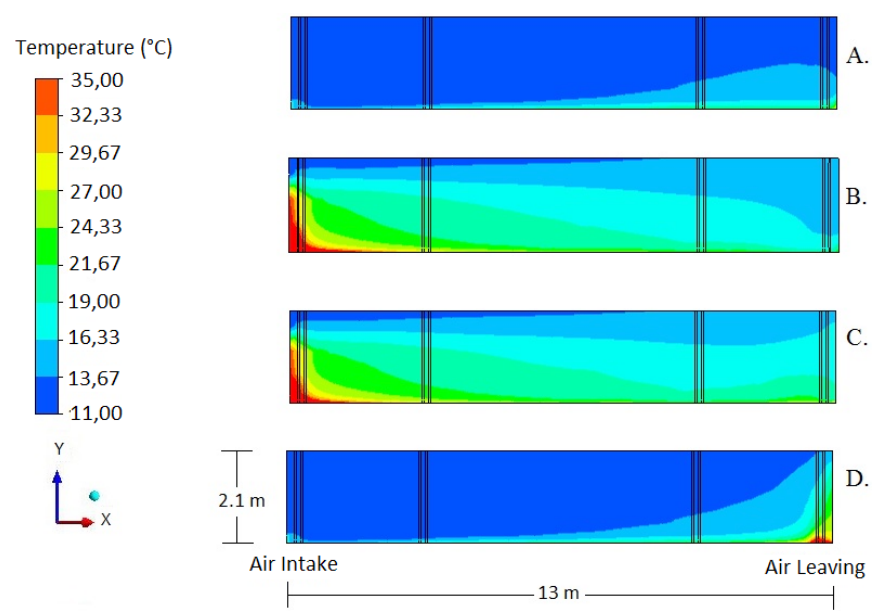

Figure 4. Temperature distribution along the $\mathrm{XY}$ plane for the different cases 
between 25 and $30{ }^{\circ} \mathrm{C}$ were encountered in the region near the air outlet. This could be due to heat accumulation in this region, since the air outlet is at ceiling height. In cases B and C, the air temperatures at the height of the chicks are between 27 and $35{ }^{\circ} \mathrm{C}$ due to low air flows, which can cause heat buildup, since the air inlet is at the height of the celling.

Figure 5 show the distribution of $\mathrm{NH}_{3}$ concentration at steady state along the $\mathrm{XZ}$ plane of the installations at the height of the chicks for the different cases, respectively. The $\mathrm{NH}_{3}$ concentrations presented at the height of the chicks are between 4 and $16 \mathrm{ppm}$ in case A, between 12 and 36 ppm in case B, between 24 and 36 ppm in case C, and between 2 and 36 in case D.

The National Institute for Occupational Safety and Health (NIOSH, 2001) recommends that $\mathrm{NH}_{3}$ concentrations should not exceed $25 \mathrm{ppm}$ for exposure times of up to $8 \mathrm{~h}$ to ensure the health of animals and workers. Thus, considering the limit recommended by NIOSH, only case A presented $\mathrm{NH}_{3}$ concentrations under $25 \mathrm{ppm}$, while in case $\mathrm{D}$, the high concentration values are found near the air outlet area, and therefore there is only a small area that is suitable for the chicks. Cases B and C presented concentrations greater than $25 \mathrm{ppm}$ in most regions of the poultry houses due to the high temperatures and low air flow, as indicated in Figures 4 and 5.

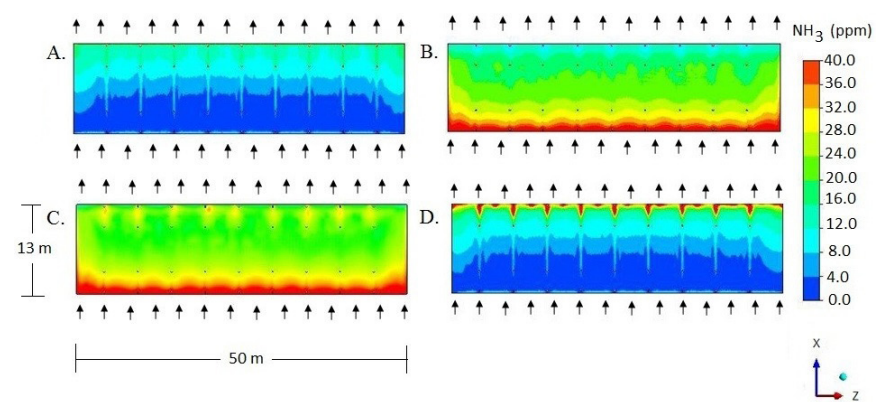

Figure 5. Distribution of $\mathrm{NH}_{3}$ concentration along the $\mathrm{XZ}$ plane at the height of the chicks in the different cases
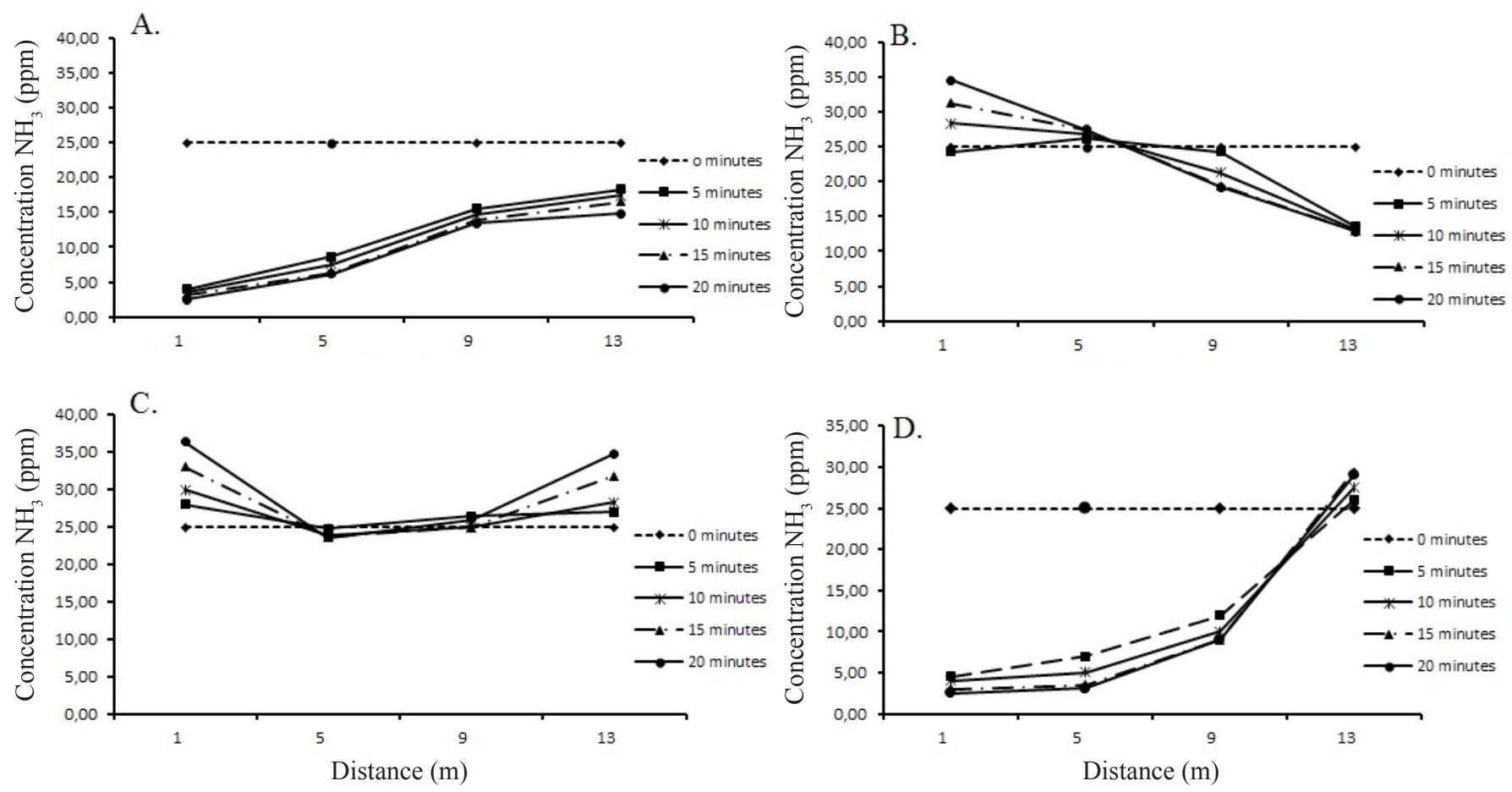

Figure 6. Behavior of $\mathrm{NH}_{3}$ concentration along the $\mathrm{XY}$ plane at the height of the chicks in the different cases

Figure 6 illustrates the behavior of $\mathrm{NH}_{3}$ concentration as a function of time along the XY plane at the height of the chicks in the different cases. In all cases, the initial condition that causes the inlets and outlets to be opened is when the concentration of $\mathrm{NH}_{3}$ inside the whole building reaches 25 ppm, in accordance with NIOSH (2001). In all cases, after the first minute the ammonia concentration in the width of the poultry house showed a strong variation. In case $A$, the ammonia concentration was below $25 \mathrm{ppm}$ for the whole time, while the opposite situation occurred in case C.

In case $\mathrm{B}$, the $\mathrm{NH}_{3}$ concentration in the middle of the width decreased almost constantly during the whole period until it reached a value close to $25 \mathrm{ppm}$; nevertheless, the concentration was below 25 ppm near the air outlet during the whole period. In case $\mathrm{D}$, high concentrations of $\mathrm{NH}_{3}$ were observed near the air vent in the first minutes and then the concentration decreased until it approached values of approximately $5 \mathrm{ppm}$. In most regions of the facilities, the concentrations were under $25 \mathrm{ppm}$ at the height of the chicks, but near the lateral wall in which the air outlet was situated, the concentrations were above $25 \mathrm{ppm}$ during the whole time.

\section{Conclusions}

1. For this particular type of installation for chicks older than 21 days, under night-time conditions with outside temperatures ranging from 10 to $15^{\circ} \mathrm{C}$, which are typical in tropical and subtropical countries, when the four cases that are typically used in the poultry industry were assessed, better behaviors were observed in cases $\mathrm{A}$ and $\mathrm{D}$, where the air inlet was located near the ground.

2. This model can be used to predict and improve the internal conditions of the poultry facilities during the night in terms of temperature and ammonia concentration control and could be an important tool to reduce energy consumption

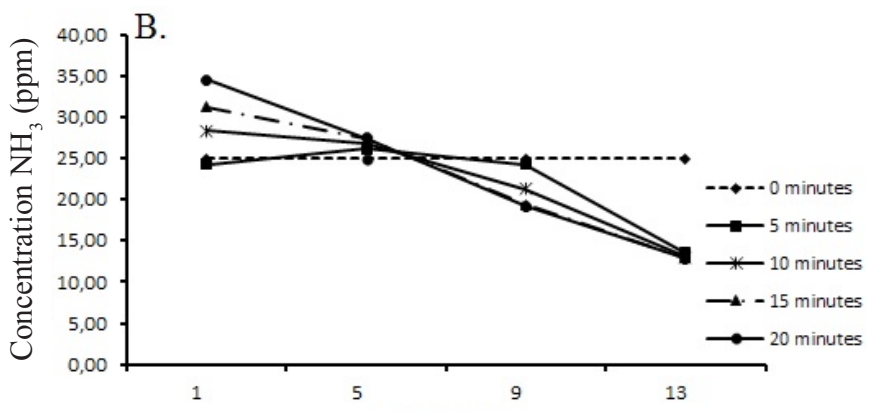

R. Bras. Eng. Agríc. Ambiental, v.21, n.12, p.852-857, 2017. 
by using natural ventilation, generating better conditions for animal production of chicks aged over 21 days.

\section{Literature Cited}

ASTM - American Society for Testing Materials. Guide for statistical evaluation of indoor air quality models (D5157-97). 2.ed. West Conshohocken: ASTM, 2002. p.68-71.

Cassuce, D. C.; Tinôco, I. de F. F.; Baêta, F. C.; Zolnier, S.; Cecon, P. R.; Vieira, M. de F. A. Thermal comfort temperature update for broiler chickens up to 21 days of age. Engenharia Agrícola, v.33, p.28-36, 2013. https://doi.org/10.1590/S0100-69162013000100004

Damasceno, F. A.; Saraz, J. A. O.; Mendes, L. B.; Martin, S.; Martins, M. A. Evaluation of a heating system in poultry houses using a CFD model. Revista Facultad Nacional de Agronomia, v.67, p.1-9, 2014. https://doi.org/10.15446/rfnam.v67n2.44178

Mendes, L. B.; Tinôco, I. de F. F.; Ogink, N. W. M.; Rocha, K. S. O.; Saraz; J. A. O.; Santos, M. S. Ammonia emissions from a naturally and a mechanically ventilated broiler house in Brazil. Revista Brasileira de Engenharia Agrícola e Ambiental, v.18, p.1179-1185. 2014. http://dx.doi.org/10.1590/1807-1929/agriambi.v18n11p1179-1185

Menegali, I.; Tinôco, I. de F. F.; Baêta, F. da C.; Cecon, P. R.; Guimarães, M. C. de C.; Cordeiro, M. B. Ambiente térmico e concentração de gases em instalações para frangos de corte no período de aquecimento. Revista Brasileira de Engenharia Agrícola e Ambiental, v. 13, p.984-990, 2009. http://dx.doi.org/10.1590/18071929/agriambi.v18n11p1179-1185

NIOSH - National Institute for Occupational Safety and Health, Ontario Ministry of the Environment. Selangor,Malaysia: Center for Disease Control and Prevention, 2001.47p.

Norton, T.; Grant, J.; Fallon, R.; Sun, D. Improving the representation of thermal boundary conditions of livestock during CFD modelling of the indoor environment. Computers and Electronics in Agriculture, v.73, p.17-36, 2010. http://dx.doi.org/10.1016/j. compag.2010.04.002

Osorio, R.; Tinôco, I. de F. F.; Saraz, J. A. O.; Souza, C. de F.; Coelho, D. J.; Souza, F. C. de. Calidad del aire en galpón avícola con ventilación natural durante la fase de pollitos. Revista Brasileira de Engenharia Agrícola e Ambiental, v.20, p.660-665. 2016. http:// dx.doi.org/10.1590/1807-1929/agriambi.v20n7p660-665

Pedersen, S.; Thomsen, M. G. Heat and moisture production of broilers kept on straw bedding. Journal of Agricultural Engineering Research, v.75, p.177-187, 2000. https://doi.org/10.1006/ jaer.1999.0497
Rocha, K. S. O.; Martins, J. H.; Martins, A. E.; Saraz, J. A. O.; Lacerda Filho, A. F. Three-dimensional modeling and simulation of heat and mass transfer processes in porous media: An application for maize stored in a flat bin. Drying Technology, v.31, p.1099-1106, , 2013. https://doi.org/10.1080/07373937.2013.775145

Rocha, K. S. O.; Martins, J. H.; Martins, A. E.; Tinôco, I. de F. F.; Saraz, J. A. O.; Lacerda Filho, A. F.; Fernandes, L. H. M. Modeling and simulation of the transient response of temperature and relative humidity sensors with and without protective housing. Plos One, v.9, p.1-10, 2014. https://doi.org/10.1371/journal.pone.0095874

Saraz, J. A. O.; Tinôco, I. de F. F.; Gates, R.; Rocha, K. S. O.; Combatt, M. E.; Sousa, F. C. de. Adaptation and validation of a methodology for determing ammonia flux generated by litter in naturally ventilated poultry houses. Revista de Ingeniería Dyna, v.81, p.137-143. 2014. https://doi.org/10.15446/dyna. v81n187.40806

Saraz, J. A. O.; Tinôco, I. de F. F.; Gates, R. S.; Rocha, K. S. O.; Marín, O. L. Z. A simple methodology to measure ammonia flux generated in naturally ventilated poultry houses. Revista Colombiana de Ciencias Pecuarias, v.28, p.3-12, 2015.

Saraz, J. A. O.; Tinôco, I. de F. F.; Rocha, K. S. O.; Mendes, L. B.; Norton, T. A CFD based approach for determination of ammonia concentration profile and flux from poultry houses with natural ventilation. Revista Facultad Nacional de Agronomia, v.69, p.110, 2016. https://doi.org/10.15446/rfna.v69n1.54750

Seo, I. H.; Lee, I. B.; Moon, O. K.; Kim, H. T.; Hwang, H. S.; Hong, S. W.; Bitog, J. P.; Yoo, J. I.; Kwon, K. S.; Kim, Y. H.; Han, J. W. Improvement of the ventilation system of a naturally ventilated broiler house in the cold season using computational simulations. Biosystems Engineering, v.104, p.106-117, 2009. https://doi. org/10.1016/j.biosystemseng.2009.05.007

Sousa, F. C. de; Tinôco, I. de F. F.; Saraz, J. A. O.; Rocha, K. S. O.; Ramirez, M. A. Saraz method adjustment for the quantification of ammonia emissions generated in opened or hybrid animal production facilities. Revista de Ingeniería Dyna, v.83, p.61-68, 2016. https://doi.org/10.15446/dyna.v83n195.48130

Vigoderis, R. B.; Cordeiro, M. B.; Tinôco, I. de F. F.; Menegali, I.; Souza Júnior, J. P. de; Holanda, M. C. R. de. Avaliação do uso de ventilação mínima em galpões avícolas e de sua influência no desempenho de aves de corte no período de inverno. Revista Brasileira de Zootecnia, v.39, p.1381-1386. 2010. https://doi. org/10.1590/S1516-35982010000600030 